\title{
Mountain Standard Time
}

National Cancer Institute

\section{Source}

National Cancer Institute. Mountain Standard Time. NCI Thesaurus. Code C116266.

Local standard time, based at the 105th meridian west of the Greenwich Observatory, established as seven hours behind Coordinated Universal T ime. 